\title{
PENGAMATAN PENDAHULUAN OVARIUM BANDIKUT (Echymipera kalubu)
}

PRELIMINARY OBSERVATION ON OVARIAN OF BANDICOOT (Echymipera kalubu)

\author{
Fahry Rafli' ${ }^{1}$, Angel N. Tethool' ${ }^{2}$, Freddy Pattiselanno ${ }^{3}$ \\ ${ }^{1}$ Alumni Jurusan Peternakan, Fakultas Peternakan UNIPA, Manokwari, \\ ${ }^{2}$ Sub-Laboratorium Reproduksi Hewan, Fakultas Peternakan UNIPA, Manokwari, \\ ${ }^{3}$ Sub-Laboratorium Satwa Harapan, Fakultas Peternakan UNIPA, Manokwari, \\ ABSTRAK
}

Article history

Accepted: May 4, 2018 ;

Approved: June 1, 2018

* Corresponding author:

E-mail:

rafli.fahry@gmail.com angel tethool@yahoo.com f.pattiselanno@unipa.ac.id
The study aimed to determine the size and physical description (location, shape, colour and texture) ovarian of Echymipera kalubu. Study was conducted in 3 months from June to September 2017. Three female E. kalubu with an average body weight $399 \pm 97.32 \mathrm{~g}$ and average body length $21.67 \pm 5.51 \mathrm{~cm}$ were used in this study. Sample of bandicoots were dissected using a surgical tool and then measured using measuring tester and analytic scales. Descriptive statistics was used to analyse the data. The results showed that average length of female reproductive organs of E. kalubu was $11,00 \pm 0,87 \mathrm{~cm}$ (right) and $11,03 \pm 0,83 \mathrm{~cm}$ (left); average weight of ovarian was $0,01 \pm 0,0048 \mathrm{~g}$ (right) and $0,02 \pm 0,0006 \mathrm{~g}$ (left). This study also showed that characteristics of ovarian were in common with other polytocus animals.

Key words: Echymipera kalubu; ovarian; reproduction; Papua

\section{PENDAHULUAN}

Sebagai satwa sumber daging oleh masyarakat setempat di Papua, bandikut mempunyai laju reproduksi yang tinggi. Dalam setahun, seekor induk bandikut bisa melahirkan 5-6 kali dengan jumlah anak per kelahiran 3-4 ekor, lama bunting 12-13 hari dan lama menyusui 50-60 hari (Petocz, 1994). Salah satu genus bandikut, Echymipera termasuk jenis satwa yang dimanfaatkan oleh masyarakat Papua sebagai sumber protein hewani (Pattiselanno, 2003), dan juga memiliki nilai etno-zoologis (Warsono, 2009).

Penggunaan bandikut sebagai model dalam penelitian hewan marsupial perlu mendapat perhatian mengingat hewan ini memiliki ukuran tubuh yang kecil sehingga memudahkan dalam penanganan, ekonomis dalam menggunakan bahan coba, lebih efisien dalam pemakaian ruang dan mudah untuk melakukan percobaan ulang (Tethool, 2011). Satwa ini memiliki struktur organ reproduksi yang unik, dimana saluran akhir alat reproduksi, saluran kencing dan saluran pembuangan kotoran bermuara dalam satu saluran anus mirip kloaka pada unggas (Warsono, 2009).
Ovarium merupakan organ reproduksi primer tempat dihasilkannya ovum atau sel telur yang akan dibuahi oleh spermatozoa (Hardjoprandjoto, 1995). Mengetahui dengan baik bentuk fisik dan anatomi ovarium akan memberikan informasi yang berguna dalam menunjang program budidaya bandikut saat ini.

\section{METODE PENELITIAN}

Penelitian ini dilaksanakan di Laboratorium Fisiologi dan Reproduksi Fakultas Peternakan Universitas Papua Manokwari Papua Barat dan penelitian ini berlangsung selama 3 bulan yaitu tanggal 15 Juni sampai dengan 15 September tahun 2017.

\section{Bahan dan Alat}

Penelitian ini menggunakan 3 organ reproduksi bandikut (Echymipera kalubu) betina. Peralatan yang digunakan antara lain: seperangkat alat bedah, pita ukur dan timbangan digital kapasitas $5 \mathrm{~kg}$ dengan ketelitian $0 \mathrm{~kg}$, timbangan analitik (Ohauss) kapasitas $200 \mathrm{~g}$ dengan ketelitian 0,001g, jarum pentul, pita ukur/mistar dan alat tulis. 


\section{Metode}

Metode deskriptif dengan teknik observasi atau pengamatan langsung di lapangan, sedangkan untuk pengukuran morfometri dan pengamatan deskripsi fisik organ reproduksi bandikut (Echymipera kalubu) betina dilakukan di Laboratorium Reproduksi Ternak Fapet Unipa. Pelaksanaan penelitian dilakukan dalam 2 tahap. Yaitu persiapan penelitian dan pelaksanaan penelitian.

Persiapan penelitian mencakup pengadaan $E$. kalubu dan penyediaan sarana dan prasarana penelitian E. kalubu betina sebanyak 3 ekor yang diperoleh dari 3 tempat yang berbeda di wilayah Kabupaten Manokwari yaitu di Amban Pantai (Distrik Manokwari Utara), Amban Angkasa Mulyono (Distrik Manokwari Barat) dan SP 9 (Distrik Prafi).

\section{Variabel Pengamatan}

Variabel yang diamati dalam penelitian ini adalah ovarium (berat dan deskripsi fisik) dan uterus (panjang, diameter dan deskripsi fisik).

Berat ovarium diukur menggunakan timbangan analitik merek Ohause berkapasitas $200 \mathrm{~g}$ dengan ketelitian $0,001 \mathrm{~g}$. Cara pengukurannya adalah mengaktifkan timbangan analitik Ohause dan menormalkan skalanya hingga mencapai angka 0 (nol), lalu ovarium diletakkan pada timbangannya maka akan terbaca berat ovarium yang ditampilkan pada skala timbangan analitik Ohause dalam satuan gram (g). Rerata berat ovarium kanan dan kiri dinyatakan sebagai kisaran berat ovarium E. kalubu.

\section{Analisis Data}

Data yang diperoleh ditabulasi kemudian dianalisis secara statistik deskriptif untuk mencari rataan dan standar deviasi.

\section{HASIL DAN PEMBAHASAN}

Berat ovarium Echymipera kalubu adalah0,01 $\pm 0,0048 \mathrm{~g}$ (kanan) dan 0,02 $\pm 0,0006$ g (kiri). Karena belum tersedia data sebagai pembanding, maka data yang diperoleh dibandingkan dengan ovarium pada Kangguru Pohon Kelabu. Berat ovarium Echymipera kalubu sangat ringan jika dibandingkan dengan berat ovarium pada kangguru Pohon Kelabu (D. inustus) yaitu

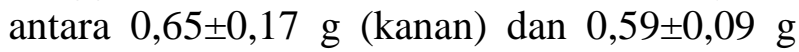
(kiri) (Koibur et al., 2011). Perbedaan tersebut dikarenakan perbedaan spesies dan bobot badan dari satwa tersebut.

Secara individu sampel 2 memiliki ovarium kiri yang paling berat $(0,0193 \mathrm{~g})$ dan ovarium kanan yang paling ringan $(0,009 \mathrm{~g})$. Kondisi ini diduga akibat dari adanya perkembangan folikel di dalam ovarium yang telah memasuki fase de Graaf pada perkembangan ovarium kiri khususnya, tetapi tidak diiukti dengan perkembangan yang sama pada ovarium bagian kanan yang diduga sedikit terhambat. Hal ini didukung oleh Toelihere $\left(1985^{\mathrm{a}}\right)$ yang melaporkan bahwa besar ovarium yang tentunya berpengaruh pada berat ovarium erat hubungannya dengan jumlah folikel de Graaf yang terbentuk. Lebih jauh dijelaskan bahwa jumlah folikel de Graaf yang terbentuk tergantung pada hereditas dan faktor- faktor lingkungan.

Jika dilihat dari perbandingan ketiga sampel, diduga karena adanya abnormalitas yang dialami oleh sampel 2, berdampak terhadap bobot ovarium individu dimaksud, karena perbedaannya yang sangat besar dibanding kedua sampel lainnya yang hanya berbeda $0,001 \mathrm{~g}$. Pengukuran terhadap bobot badan menunjukan hal yang sama dimana bobot badan sampel 2 lebih kecil dibanding sampel 1 dan sampel 3. Hardjopranjoto (1995) menegaskan bawha adanya kejadian pada satu individu ternak, dapat terjadi pada salah satu organ atau keseluruhan salah satu bagian organ kelaminnya (jantan maupun betina). Kemungkinan karena mengalami abnormalitas maka hal itu ikut mempengaruhi perkembangan yang bersifat genetik maupun lingkungan sehingga organ tersebut cenderung lebih besar atau kecil dari kondisi normal umumnya.

Pendapat ini dibenarkan Hafez (2000) yang menyatakan bahwa ada kecenderungan salah satu atau seluruh bagian organ reproduksi (jantan maupun betina) bagian kiri (terkadang kanan namun jarang ditemukan) mengalami perkembangan yang tidak sempurna (rudimenter) sehingga tampak sangat kecil bahkan tidak ada. Diduga, hal 
tersebut terjadi sebagai akibat pengaruh lingkungan maupun hereditas individu hewan dimaksud. Ukuran ovarium sangat tergantung pada umur dan siklus reproduksinya (Nalbandov, 1990).

Ovarium Echymipera kalubu terletak di bawah kolon (usus besar). Namun menurut Hardjopranjoto (1995) letak ovarium dapat berubah-ubah karena adanya kebuntingan maupun umur yang bertambah. Bentuknya menyerupai buah anggur. Hal ini didukung oleh (Nalbandov, 1990) yang menyatakan ovarium pada beberapa mamalia memiliki bentuk oval seperti anggur. Memiliki warna merah hati, warna merah hati pada ovarium diduga akibat pengaruh hormonal dan kapiler darah. Sejalan dengan pernyataan tersebut, Toelihere (1981) menjelaskan bahwa pada fase de Graaf, folikel tumbuh di bawah pengaruh FSH (Folikel Stimulating Hormon) dan menghasilkan estradiol, sehingga folikel berkembang dan diisi cairan folikuler. Estradiol meningkatkan suplai darah ke saluran alat kelamin dan meningkatkan perkembangan folikel pada ovarium. Ovarium memiliki tekstur bergerigi kenyal.

\section{KESIMPULAN}

Hasil studi menunjukkan bahwa ovarium pada E. kalubu memiliki persamaan dengan hewan polytocus lainnya. Perlu dilakukan penelitian lanjutan untuk mempelajari histologi organ reproduksi, tingkah laku reproduksi dan fisiologi reproduksi bandikut (Echymipera kalubu) betina dalam penangkaran.

\section{DAFTAR PUSTAKA}

Broughton S. K., Dickman C. R. 1991. The Effect of Supplementary Food on Home Range of The Southern Brown Bandicoot, Isoodon obesulus (Marsupialia: Peramelidae). Aust. J. of ecology. 169(1):71-78.

Flannery T. $1995^{\mathrm{a}}$. Mammals of New Guinea. The Australian Museum.

Flannery T. $1995^{\mathrm{b}}$. Mammals of the SouthWest Pacific and Moluccas Islands. The Australian Museum.
Hafez, E. S. E. 2000. Anatomy of Female Reproduction, in Reproduction in Farm Animals, Hafez, E.S.E. ad, $7^{\text {th }}$ ed. Lea \& Febiger. Philadelphia.

Hardjopranjoto S. H. 1995. Ilmu Kemajiran Ternak. Bab 2 hal: 19-29. Airlangga University Press. Surabaya.

IUCN. 2008. IUCN Red List of Threatened Species. http://www.iucnredlist.org (22 Agustus 2017).

Koibur J. F. Kustono dan Widayati D. T. 2011. Karakteristik dan Organ Reproduksi Betina Kangguru Pohon Kelabu (Dendrolagus inustus) di Papua. Buletin Peternakan Vol. 35 (1): 17-23, Februari 2011. ISSN 0126-4400. Manokwari Papua Barat.

Nalbandov R. 1990. Fisiologi Reproduksi pada Mamalia dan Unggas. Fisiologi Komparatif pada Hewan Domestikasi dan Laboratorium serta Manusia (diterjemahkan oleh Sunaryo). Jakarta: UI Press.

Pattiselano F. 2003. The Wildlife Value: Example from West Papua, Indonesia. Tigerpaper Vol. 30 (1): 29-27.

Petocz R. G. 1994. Mamalia Darat Irian Jaya. Penerbit Gramedia Pustaka Utama. Jakarta. Hal. 69-77.

Strahan R. 1990. The Australian Museum. Complete Book of Australian Mammals. The National Photographic Index of Australian Wildlife. Angus and Robertson Publisher.

Tethool A. N. 2011. Karakteristik Reproduksi Bandikut (Echymipera kalubu) Jantan. Tesis. Bogor: Sekolah Pascasarjana, Institut Pertanian Bogor.

Toelihere M. R. 1985. Fisiologi Reproduksi pada Ternak. Penerbit Angkasa. Bandung.

Toelihere M. R. 1981. Inseminasi Buatan pada Ternak. Penerbit Angkasa. Bandung.

Warsono I. U. 2009. Sifat Biologis dan Karakteristik Karkas dan Daging Bandikut (Echymipera kalubu). Disertasi. Bogor: Sekolah Pascasarjana, Institut Pertanian Bogor. 